\title{
A comprehensive survey of copy number variation in 18 diverse pig populations and identification of candidate copy number variable genes associated with complex traits
}

Congying Chen ${ }^{1 \dagger}$, Ruimin Qiao ${ }^{1 \dagger}$, Rongxing Wei ${ }^{1,2 \dagger}$, Yuanmei Guo ${ }^{1}$, Huashui $\mathrm{Ai}^{1}$, Junwu Ma ${ }^{1}$, Jun Ren ${ }^{1}$ and Lusheng Huang ${ }^{1 *}$

\begin{abstract}
Background: Copy number variation (CNV) is a major source of structural variants and has been commonly identified in mammalian genome. It is associated with gene expression and may present a major genetic component of phenotypic diversity. Unlike many other mammalian genomes where CNVs have been well annotated, studies of porcine CNV in diverse breeds are still limited.

Result: Here we used Porcine SNP60 BeadChip and PennCNV algorithm to identify 1,315 putative CNVs belonging to 565 CNV regions (CNVRs) in 1,693 pigs from 18 diverse populations. Total 538 out of 683 CNVs identified in a White Duroc $\times$ Erhualian $F_{2}$ population fit Mendelian transmission and 6 out of 7 randomly selected CNVRs were confirmed by quantitative real time PCR. CNVRs were non-randomly distributed in the pig genome. Several CNV hotspots were found on pig chromosomes 6, 11, 13, 14 and 17. CNV numbers differ greatly among different pig populations. The Duroc pigs were identified to have the most number of CNVs per individual. Among 1,765 transcripts located within the CNVRs, 634 genes have been reported to be copy number variable genes in the human genome. By integrating analysis of QTL mapping, CNVRs and the description of phenotypes in knockout mice, we identified 7 copy number variable genes as candidate genes for phenotypes related to carcass length, backfat thickness, abdominal fat weight, length of scapular, intermuscle fat content of logissimus muscle, body weight at 240 day, glycolytic potential of logissimus muscle, mean corpuscular hemoglobin, mean corpuscular volume and humerus diameter.

Conclusion: We revealed the distribution of the unprecedented number of 565 CNVRs in pig genome and investigated copy number variable genes as the possible candidate genes for phenotypic traits. These findings give novel insights into porcine CNVs and provide resources to facilitate the identification of trait-related CNVs.
\end{abstract}

Keywords: Copy number variation, Copy number variable gene, Complex trait, QTL, Pig

\footnotetext{
* Correspondence: Lushenghuang@hotmail.com

${ }^{\dagger}$ Equal contributors

'Key Laboratory for Animal Biotechnology of Jiangxi Province and the

Ministry of Agriculture of China, Jiangxi Agricultural University, Nanchang

330045, China

Full list of author information is available at the end of the article
} 


\section{Background}

Copy number variation (CNV), a major type of structural variants, is defined as DNA segments that vary from one kilobase to several megabases in length and present at variable copy numbers in comparison with a reference genome $[1,2]$. Following the completion of pig whole-genome sequencing, genome-wide polymorphisms including CNV, SNP and deletion/insertion will be well annotated in the near future. Currently, Porcine 60K SNP BeadChips are commercially available for genome-wide analyses of 62,163 SNPs. However, a comprehensive study of genome-scale CNVs in pigs remains unexplored.

Tilling oligonucleotide array and comparative genomic hybridization (CGH) array have been commonly used to detect whole-genome CNVs. In recent years, wholegenome SNP genotyping arrays offer alternative methods for $\mathrm{CNV}$ detection [3]. Computer programs like PennCNV [4], QuantiSNP [5], cnvPartition (Illumina) and CNV Workshop [6] have been developed to identify CNVs from SNP array data. The unique ability to integrate family relationships from parent-offspring trios, total signal intensity and allelic intensity ratio at each SNP marker, and the allele frequency of SNP makes PennCNV algorithm have a moderate power and the lowest false positive rate [4]. Winchester et al. (2009) reported that PennCNV is the most accurate program in the prediction of CNVs for the Illumina's platform by comparing different algorithms for CNV detection [7].

CNVs have been commonly identified in humans, rats, dogs, cattle and horse, and occupy about 3.7\%, 1.4\%, 4.2\%, $4.6 \%$ and $3.6 \%$ of their assembled genome, respectively [8-12]. It has been estimated that CNVs account for at least $17.7 \%$ of heritable variation of gene expression in a variety of ways including gene dosage effects, disruption of gene coding region and deletion or duplication of regulatory elements [13]. In humans, SNP-tagged CNVs are enriched for expression quantitative trait loci (eQTL) [14]. CNVs have been confirmed to associate with Mendelian diseases and complex genetic disorders in humans, such as schizophrenia [15], body mass index [16], Crohn's disease [17] and intellectual disability and various congenital defects [18]. Similarly, in livestock, more and more studies evidenced that CNVs play causative effects on phenotypic variations, such as $\mathrm{CNV}$ in intron 1 of SOX5 causing the pea-comb phenotype in chickens [19], a 4.6-kb intronic duplication in STX17 for hair greying and melanoma in horses [20], duplication of FGF3, FGF4, FGF19 and ORAOV1 resulting in hair ridge and predisposition to dermoid sinus in Ridgeback dogs [21], and CNV and missense mutations of the agouti signaling protein (ASIP) gene leading to different coat colors in goats [22]. But in pigs, few such examples have been reported at present. $K I T$ is the first pig gene that has been confirmed that gene duplication and a splice mutation leading the skipping of exon 17 are responsible for the dominant white phenotype and peripheral blood cell [23,24].

Until now, to our knowledge, there are only three studies on pig CNV discovery. Fadista et al. (2008) found 37 CNVRs across chromosome (SSC) 4, 7, 14 and 17 using a custom tilling oligonucleotide array [25]. Tang et al. (2010) investigated the CNV distribution on SSC7 and SSC8 by CGH array [26]. More recently, Ramayo-Caldas et al. (2010) detected 49 CNVRs in porcine autosomal chromosomes in 55 animals from an Iberian $\times$ Landrace cross with Porcine SNP60 BeadChip [27]. However, the distribution of CNVs in large scale and diverse pig populations remains largely unknown.

We herein used Porcine SNP60 BeadChip and PennCNV algorithm to identify porcine autosomal CNVs in 1,693 animals from 18 populations, and analyzed the CNV distribution in pig genome and different populations. We compared the identified CNVs with the reported porcine CNV call sets and investigated the copy number variable genes. Especially, we used a large scale White Duroc $\times$ Erhualian $\mathrm{F}_{2}$ intercross, in which the QTL were mapped for 422 traits [28]. The intercross allowed us to systematically investigate the effects of pig CNVs on phenotypic variations.

\section{Results and discussion}

\section{CNV discovery, distribution and validation}

Experimental samples were recruited from 18 pig populations including 10 Chinese indigenous breeds with different geographical origins, 2 Western commercial breeds, 1 wild boar and $5 \mathrm{~F}_{2}$ resource populations (Table 1). The Porcine SNP60 BeadChip data that passed quality control in a panel of 1,693 animals were included in the analysis of CNVs by PennCNV. We used a calling criterion of spanning three or more consecutive SNPs and standard deviation of $\log \mathrm{R}$ Ratio $\leq 0.35$. The chromosomes $\mathrm{X}$ and $\mathrm{Y}$ were excluded from our analysis. As a result, we totally identified 2,122 putative CNVs in 1,327 individuals including 971 population-specific CNVs. These CNVs are located in all 18 autosomes with a mean size of $223.51 \mathrm{~kb}$ ranging from $50.02 \mathrm{~kb}$ to $5.64 \mathrm{Mb}$. The predicted status for the CNVs was 1,149 (54.15\%) for deletion, 964 (45.43\%) for duplication and $9(0.42 \%)$ for regions with either deletion or duplication status according to different animals (Table 1).

Merging identical CNVs from all animals across breeds yielded 1,315 unique CNVs out of the 2,122 putative CNVs. CNVRs were determined by aggregating overlapping unique CNVs. The 1,315 unique CNVs were clustered into a set of 565 non-redundant CNVRs which encompassed about $143.03-\mathrm{Mb}$ region equaling approximately $5.84 \%$ of the pig genome (Figure 1). These 565 CNVRs were all called in $\geq 2$ individuals and included 261 loss, 225 gain and 79 both (Additional file 1: Table S1). The sizes of these CNVRs ranged from $50.39 \mathrm{~kb}$ to $8.10 \mathrm{Mb}$, with a median size of $252.71 \mathrm{~kb}$ (Additional file 1: Table S1). This size 
Table 1 Identification of CNVs in 18 diverse pig populations

\begin{tabular}{|c|c|c|c|c|c|c|c|}
\hline \multirow[t]{2}{*}{ Breed } & \multirow{2}{*}{$\begin{array}{l}\text { Number } \\
\text { of } \\
\text { animals } \\
\text { identified } \\
\text { CNV }\end{array}$} & \multicolumn{2}{|c|}{ Number of CNVs } & \multicolumn{3}{|c|}{ Status of CNVs } & \multirow{2}{*}{$\begin{array}{l}\text { Average } \\
\text { Size(kb) }\end{array}$} \\
\hline & & Total & Unique & Gain & Loss & Gain/Loss & \\
\hline White Duroc $\times$ Erhualian $F_{2}$ intercross & 752 & 683 & 456 & 370 & 305 & 8 & 227.21 \\
\hline Bamaxiang $\times$ Erhualian $F_{2}$ intercross & 77 & 92 & 30 & 41 & 51 & - & 184.42 \\
\hline Rongchang $\times$ Erhualian $F_{2}$ intercross & 87 & 159 & 48 & 65 & 94 & - & 218.72 \\
\hline Shazilin $\times$ Erhualian $F_{2}$ intercross & 156 & 254 & 149 & 153 & 101 & - & 240.92 \\
\hline Tongcheng $\times$ Erhualian $\mathrm{F}_{2}$ intercross & 51 & 104 & 22 & 53 & 51 & - & 218.52 \\
\hline Bamaxiang & 15 & 66 & 35 & 7 & 59 & - & 206.91 \\
\hline Dongshan & 9 & 35 & 12 & 12 & 23 & - & 215.13 \\
\hline Duroc & 10 & 124 & 52 & 13 & 111 & - & 220.26 \\
\hline Erhualian & 16 & 48 & 6 & 16 & 32 & - & 232.96 \\
\hline Jinghua & 14 & 75 & 40 & 19 & 56 & - & 191.21 \\
\hline Minzhu & 15 & 46 & 6 & 22 & 23 & 1 & 230.86 \\
\hline Rongchang & 63 & 180 & 64 & 90 & 90 & - & 194.64 \\
\hline Shanggao Two-End-Black & 10 & 31 & 6 & 7 & 24 & - & 170.79 \\
\hline Shazilin & 8 & 34 & 5 & 12 & 22 & - & 144.51 \\
\hline Sutai & 10 & 57 & 13 & 22 & 35 & - & 206.23 \\
\hline Tongcheng & 15 & 50 & 12 & 23 & 27 & - & 153.23 \\
\hline White Duroc & 3 & 23 & 0 & 6 & 17 & - & 183.52 \\
\hline wild boar & 16 & 61 & 15 & 33 & 28 & - & 141.83 \\
\hline Total & 1,327 & 2,122 & 971 & 964 & 1,149 & 9 & - \\
\hline Average & - & 117.89 & 53.94 & 53.56 & 63.83 & 0.50 & 223.51 \\
\hline
\end{tabular}

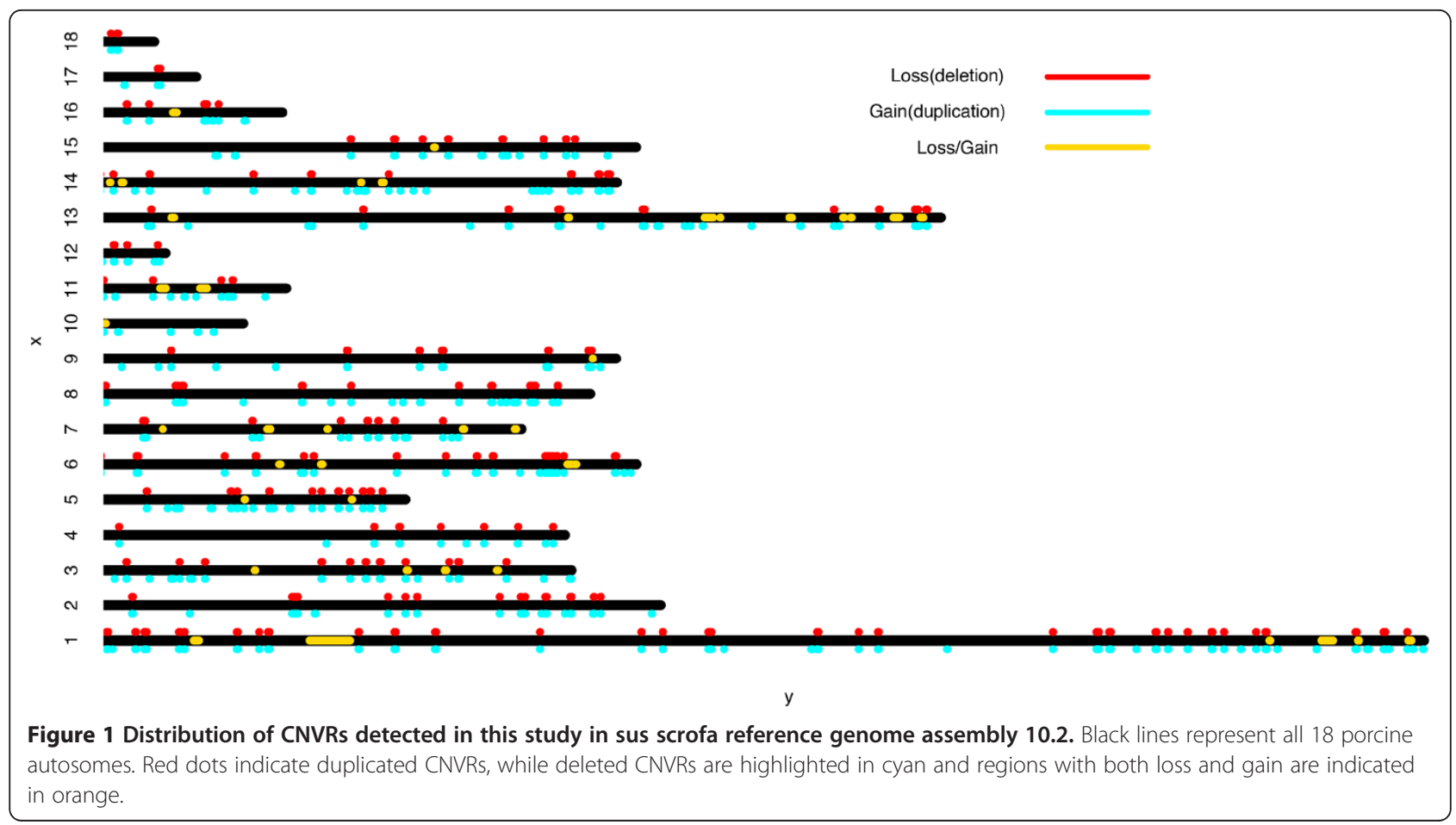


range was significantly different from that of detected by the CGH array (ranged from 1.74 to $61.92 \mathrm{~kb}$ ) [25]. This difference may be explained by the relatively low coverage and the non-uniform distribution of SNPs in Porcine SNP60 BeadChip in the pig genome [29]. But we noted that the size range in this study was similar to that in RamayoCaldas et al. (2010) where CNVRs were also called with genotyping data from Porcine SNP60 BeadChip [27].

Just as the cases in human [11] and cattle [30], we found that the CNVRs were non-randomly distributed across the pig genome. Chromosome 4, for instance, has only $2.02 \%$ of sequences showing copy number variable, while chromosome 18 has $>18.01 \%$ of sequences with copy number variation. Several "hotspots" of copy number variation were obsevered in this study, such as SSC6: 138.40-145.74 Mb, SSC11: 43.58-46.62 Mb, SSC13:213.45-215.94 Mb, SSC14: 2.74-7.42 $\mathrm{Mb}$ and SSC17: 8.25-10.28 Mb. These regions contain clusters of four to six CNVRs, indicating CNV hotspots (Additional file 1: Table S1; Figure 1).

The quality of our CNV calls was assessed in multiple ways. Our first assessment was a comparison against a previously reported porcine CNV dataset identified in 55 animals from an Iberian $\times$ Landrace cross with Porcine SNP60 BeadChip [27]. We found 30 CNVRs that overlapped with CNVRs in that dataset, accounting for $61.22 \%$ of their CNV calls (Figure 2). The $38.78 \%$ of unreplicated CNVRs is most likely due to different genetic background of pig populations in two studies, and certainly, false positive can not be excluded. For $683 \mathrm{CNVs}$ detected in the White Duroc $\times$ Erhualian $F_{2}$ resource population, we validated their Mendelian transmission using family information. Total 538 out of 683 CNVs fit Mendelian transmission (78.77\%). Finally, a total of 7 CNVRs were randomly selected for validation by quantitative real time PCR assays (CNVR329, 361, 419, 482, 502, 509 and 531; Additional file 2: Table S3). Except CNVR509 for which none of 6 animals were confirmed for this

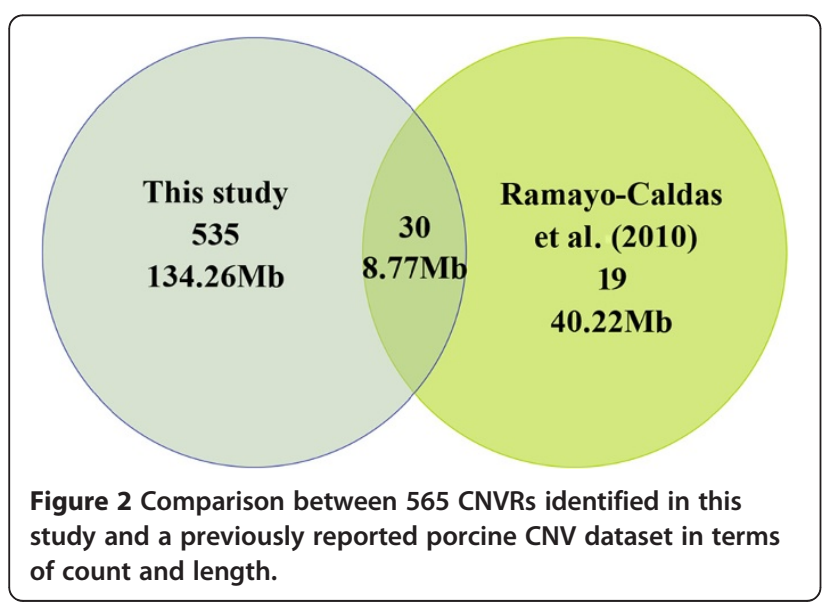

CNVR, we validated the other 6 CNVRs (Additional file 3: Figure S1).

\section{Porcine CNV frequencies among breeds}

Like CNV frequencies in humans [31], CNV numbers differ greatly among different pig populations. The average number of CNVs per population was 117.89 , ranging from 23 (White Duroc) to 683 (White Duroc $\times$ Erhualian $\mathrm{F}_{2}$ intercross). The most number of CNVs per sample was detected in Duroc pigs (12.40 CNVs per animal on average), in comparison with the least number of 0.91 CNVs per animal in the White Duroc $\times$ Erhualian $F_{2}$ intercross (Table 1).

Of the 565 CNVRs, only 20 CNVRs were detected in more than $50 \%$ of populations (9 populations). Similar to the finding in humans [31], most CNVRs (72.87\%) were restricted to one population. This should be due to sampling variances or the fact that they were recent evolution events. Among 18 diverse populations, the largest number of 310 CNVRs was identified in the White Duroc $\times$ Erhualian $\mathrm{F}_{2}$ intercross (Additional file 4: Table S2). It is most likely due to the fact that this population was a cross between European and Asian divergent breeds. Of these 310 CNVRs, 215 were unique to this resource population. As two Western pig breeds (Duroc and White Duroc) used in this study, we found that all 5 CNVRs identified in White Duroc were included within 42 CNVRs detected in Duroc. It is consistent with the fact that White Duroc is one of specialized lines of Duroc. Total 26 CNVRs were unique to the two Western breeds. Among Chinese indigenous pig breeds, the most number of 30 CNVRs was identified in both Jinhua and Shazilin. Moreover, Jinhua had the highest average number of CNVs per individual (5.36 per individual; Additional file 4: Table S2).

\section{Gene content of CNV regions}

The BioMart gene database based on the Sscrofa 10.2 reference genome assembly [32] was used to retrieve genes within the detected CNVRs. A total of 1,764 transcripts were annotated within 320 out of 565 putative CNVRs, including 1,546 transcripts completely located within the CNVRs and 218 transcripts overlapping with the CNVRs. These 1,764 transcripts were composed of 1,587 protein coding genes, 37 pseudogenes, 1 retrotransposed genes, 42 miRNAs, 7 rRNAs, 36 snoRNAs, 47 snRNAs and 7 miscRNAs. No annotated transcripts were identified within the other 235 CNVRs. Of the 1,587 protein coding genes, 1,055 genes were well annotated in pigs including 634 genes that have CNVs in the human genome (Additional file 5: Table S4) [33]. The average gene number per $\mathrm{Mb}$ in CNVRs was 13.26, 14.74 and 6.01, respectively, for gain, loss and gain/loss. However, compared to the average gene number per $\mathrm{Mb}$ in whole genome, the CNVRs have higher gene density 
(11.21 vs. 8.37). This result was consistent with the findings in other species in which a higher gene content was discovered in CNVRs $[9,29,30]$.

$\mathrm{CNV}$-associated genes or copy number variable genes have a wide spectrum of molecular functions and provide a resource for investigating the biological relationship of CNVs with the genetic basis of phenotypic variations. We performed the gene ontology (GO) analysis by querying each copy number variable gene into the records of the GO database [34]. Similar to GO annotation of CNV-associated genes in humans and rats $[9,30]$, the main terms of molecular function are related to olfactory receptor activity, G-protein coupled receptor activity, transmembrane receptor activity, receptor activity, molecular transducer activity and signal transducer activity. In the cellular component category, the most significant term was plasma membrane (corrected $P=2.70 \times 10^{-4}$ ). Among GO biological processes, the most overrepresented one was sensory perception of smell $\left(P=5.50 \times 10^{-18}\right.$, Figure 3$)$. Most these terms relate to the olfactory receptors. This may be due to the fact that total 84 olfactory receptor genes were included in the detected copy number variable genes.

We found that many CNV-associated genes appear to be certain gene clusters or families, such as olfactory receptor family, solute carrier family, apolipoprotein gene family, myosin gene family, CD gene family, cytochrome $C$ oxidase gene family, interleukin gene family, protocadherin gamma gene cluster, beta defensin protein family, neuroblastoma breakpoint family, zinc finger protein family and ring finger protein family (Additional file 5: Table S4). Some of these gene families have been well characterized and play important roles in biological processes [27,35]. For example, olfactory receptor family is the most well characterized CNV-related genes in humans [35]. Over 400 human olfactory receptor genes are reported to be variable in copy number [36]. In this study, total 84 olfactory receptor genes were located within CNVRs. More than 15 members of solute carrier family were detected in CNVRs in this study. Solute carrier family encodes membrane transport proteins including over 300 members organized into 51 families. The family proteins play important roles in transportation and exchange of ion, amino acid and other substance which take part in important biological process [37].

\section{Identification of copy number variable genes as potential} candidate genes for complex traits

The potentially disruptive effect of CNVs on gene expression, structure and function indicates that CNVs are

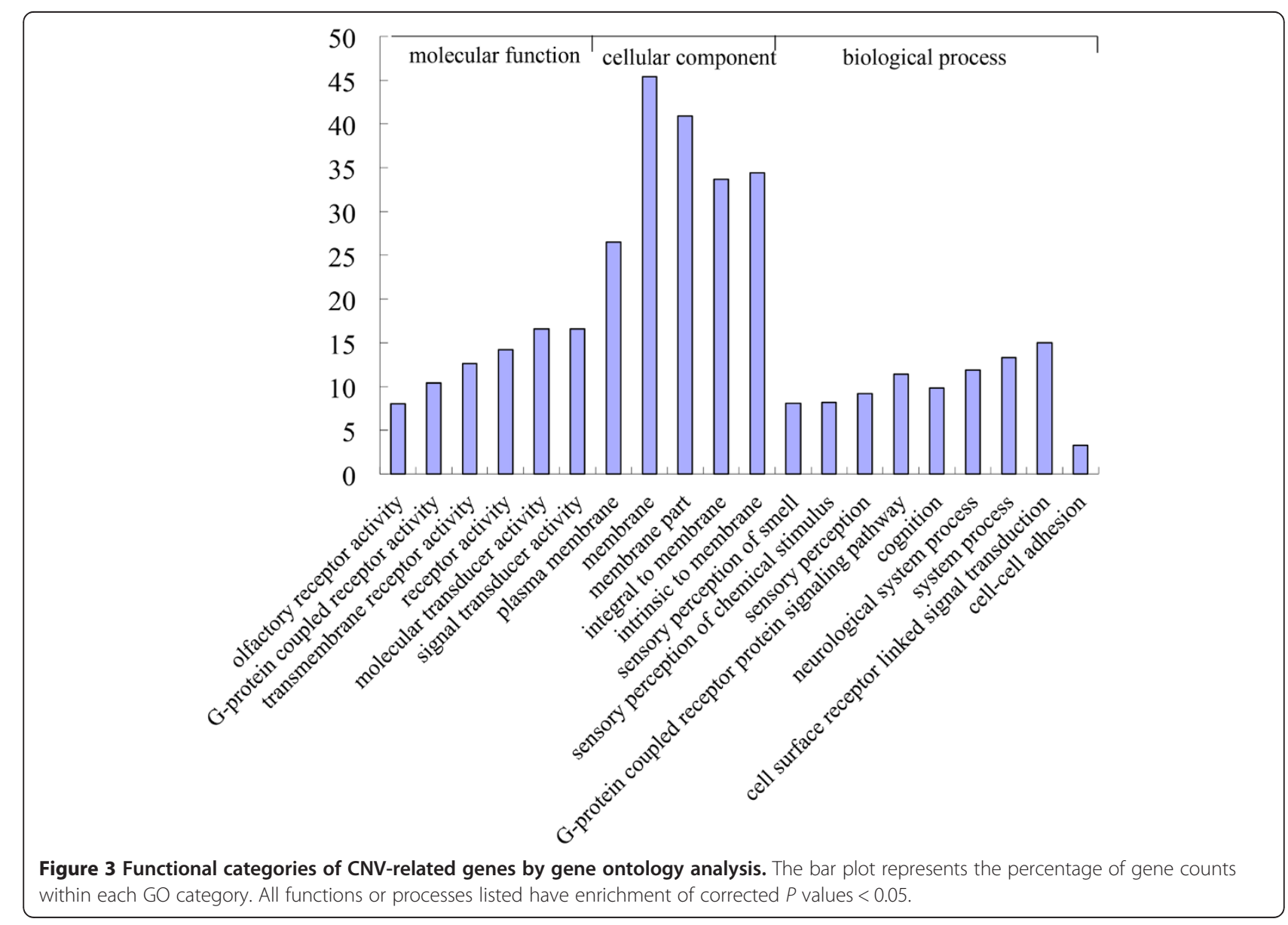


likely to contribute to phenotypes. Before this study, a genome-wide QTL mapping for traits of blood parameter [38], meat quality [39], fatness [40], growth [40], reproduction [41,42], immune capacity [43] and body conformation [44] was carried out in the White Duroc $x$ Erhualian $\mathrm{F}_{2}$ resource population and all QTL have been published and deposited in the pig QTL database [45]. In this study, all QTL above 5\% genome-wide significance level were chose to match with CNVRs identified in the White Duroc $\times$ Erhualian $F_{2}$ resource population. By integrating analysis of QTL mapping, CNVRs and the description of phenotypes in knockout mice, we identified $7 \mathrm{CNV}$ genes including $A N P 32 B, B S C L 2$, LTBP3, GDF3, GYS1, KIT and CAV1 as potential candidate genes for phenotypes related to carcass length, backfat thickness, abdominal fat weight, length of scapular, intermuscle fat content of logissimus muscle (LD), body weight at 240 day, glycolytic potential of LD, mean corpuscular hemoglobin $(\mathrm{MCH})$, mean corpuscular volume (MCV) and humerus diameter (Table 2).

We further chose KIT as a proof-of-principle example as the confirmed association between KIT duplication and $\mathrm{MCH}$ and $\mathrm{MCV}$. Previous studies have confirmed that KIT regulatory mutations including the gene duplication and splice mutation are responsible for the dominant white phenotype in pigs and have pleiotropic effects on peripheral blood cell measures in Western commercial pigs [23,24]. A significant QTL for $\mathrm{MCH}$ and MCV at day 240 was detected at SSC8: 43,550,231 in the White Duroc $\times$ Erhualian $F_{2}$ resource population [43], which fell within the genomic region of CNVR268 (SSC8: 43,425,758-43,955,459; Table 2). More than $378 \mathrm{~F}_{2}$ animals from the intercross inherited this $\mathrm{CNV}$ variant. Two genes of KIT and KDR were located within this CNVR. The KIT knockout mice exhibited phenotypes of increased mean corpuscular volume, decreased hemoglobin content and diluted coat color [54]. Furthermore, association analysis showed that CNV268 was significantly associated with $\mathrm{MCH}$ and $\mathrm{MCV}$ in the White Duroc $\times$ Erhualian $\mathrm{F}_{2}$ resource population $\left(P=1.17 \times 10^{-5}\right)$. And if we included the CNV268 as fixed effect in QTL mapping, the QTL on SSC8 for MCH and MCV was never detected again.

Moreover, the result obtained in this study was also consistent with the causative relation between KIT duplication and dominant white coat color identified before [56]. The CNVR268 harboring KIT was detected only in the solid white breed White Duroc. It was absent in all other pigs from diverse populations having colored phenotypes. It is noteworthy that the CNVR was either not found in Chinese belt-like breeds including Bamaxiang, Dongshan, Shanggao, Jinhua, Shazilin and Tongcheng, or in Rongchang pigs with the white coat color. This was in agreement with our previous conclusions that the beltlike and white coat colors in Chinese pigs were not caused by the dominant white allele of KIT [57,58].

Although some identified copy number variable genes were not overlapped with our reported QTL, they have been reported to associate with complex traits in pigs, humans or mice. For instance, we detected an 836.67-kb CNV in SSC6: 49,802,217-50,638,891 in the White Duroc $\times$ Erhualian resource population. This region contains the alpha-1-fucosyltransferase (FUT1) gene. FUT1 has been identified as a strong candidate gene encoding the intestinal Escherichia coli F18 receptor that determines susceptibility to oedema disease, post-weaning diarrhoea in Western piglets and total number of born piglets [59,60]. APOE/C4/C2 gene cluster is located within a 427.46-kb CNV region on SSC6: 46,893,592$47,321,053$. The $A P O E / C 1 / C 4 / C 2$ gene cluster variation in humans is associated with plasma lipids, particularly low density lipoprotein (LDL) level and coronary heart

Table 2 Identification of potential candidate CNV genes for complex traits in the White Duroc $\times$ Erhualian $F_{2}$ population

\begin{tabular}{|c|c|c|c|c|c|}
\hline CNVR ID & CNVR region & Trait of overlapped QTL* & CNV gene & Phenotype in knockout mice & Reference \\
\hline CNVR41 & chr1: $267,977,629-268,124,492$ & carcass length & ANP32B & decreased body size & {$[39,46]$} \\
\hline \multirow[t]{2}{*}{ CNVR62 } & chr2: $8,244,738-8,884,302$ & Backfat thickness & $\mathrm{BSCL} 2$ & decreased subcutaneous adipose tissue & {$[40,47]$} \\
\hline & & abdominal fat weight & $\mathrm{BSCL} 2$ & decreased retroperitoneal fat pad weight & {$[40,47]$} \\
\hline CNVR61 & chr2: $5,766,853-6,201,646$ & length of scapular & LTBP3 & decreased length of long bones & {$[44,48]$} \\
\hline \multirow[t]{2}{*}{ CNVR169 } & chr5: 65,533,763-65,810,346 & intermuscle fat content of LD & GDF3 & decreased white adipose tissue amount & {$[39,49]$} \\
\hline & & body weight at 240 days & GDF3 & abnormal developmental patterning & {$[40,50]$} \\
\hline CNVR199 & chr6: 49,802,217-50,638,891 & Glycolytic potential of LD & GYS1 & decreased skeletal muscle glycogen level & {$[39,51]$} \\
\hline \multirow[t]{3}{*}{ CNVR268 } & chr8: $43,425,758-43,955,459$ & mean corpuscular volume & KIT & increased mean corpuscular volume & {$[43,52]$} \\
\hline & & mean corpuscular hemoglobin & $\mathrm{KIT}$ & decreased hemoglobin content & {$[43,53]$} \\
\hline & & & & diluted coat color & {$[54]$} \\
\hline CNVR560 & chr18: $27,001,689-32,149,496$ & Humerus diameter & CAV1 & increased bone size and stiffnes & {$[44,55]$} \\
\hline
\end{tabular}

* QTL identified in the White Duroc $\times$ Erhualian resource population. 
disease [61]. CNVR128 (SSC3: 120,293,272-120,344,603) harbors $H A D H A$ and $H A D H B$, encoding the mitochondria trifunctional protein (MTP) alpha- and beta-subunits, respectively. The $H A D H A-H A D H B$ deficient mice had a decreased weight gain and cardiac arrhythmias [62].

\section{Conclusions}

In this study, we revealed the distribution of the unprecedented number of 565 CNVRs in 1,327 pigs from 18 diverse populations, and found that CNVRs were nonrandomly distributed in the porcine genome. CNV numbers differ greatly among diverse populations. More than $72.87 \%$ of CNVRs were restricted to one population. The main functional categories of CNV-related genes were similar to those of in other mammals. With the QTL mapping data and the identified CNVRs in the White Duroc $\times$ Erhualian $F_{2}$ intercross, and the description of phenotypes in knockout mice, we identified 7 copy number variable genes as potential candidate genes for porcine complex traits. These findings give novel insights into porcine CNVs and provide resources to facilitate the further identification of trait-related CNVs.

\section{Methods}

Animals

A total of 1,693 animals from 18 pig populations including 10 Chinese indigenous breeds, 2 Western commercial breeds, 1 wild boar and $5 \mathrm{~F}_{2}$ resource populations comprising White Duroc $\times$ Erhualian, Bamaxiang $\times$ Erhualian, Rongchang $\times$ Erhualian, Shazilin $\times$ Erhualian and Tongcheng $\times$ Erhualian were used in this study (Table 1). Thereinto, 1,021 animals were obtained from the large scale White Duroc $\times$ Erhualian $F_{2}$ resource population in which two White Duroc boars and 17 Erhualian sows were crossed as founder animals to produce $F_{1}$ animals, and $59 F_{1}$ sows were randomly mated with $9 \mathrm{~F}_{1}$ boars to generate $1,912 \mathrm{~F}_{2}$ individuals. Total 422 traits related to growth, meat quality, body composition, blood physiological and biochemical parameters, reproduction and immune capacity were well phenotyped in this intercross and genome-wide QTL mapping was carried out for these traits [38-44]. All animal procedures were conducted according to the guidelines for the care and use of experimental animals established by the Ministry of Agriculture of China.

\section{Genome-wide SNP genotyping}

Genomic DNA was extracted from ear or spleen tissues with the routine phenol/chloroform extraction method. All 1,693 animals were genotyped with Porcine SNP60 BeadChip using the Infinium HD Assay Ultra protocol (Illumina Inc., San Diego, USA). The position of each SNP in the pig genome assembly (Sscrofa10.2) was determined by SOAP2 software [63]. The quality control of genotypes was performed with GenABEL procedure in $\mathrm{R}$. The SNPs in sex chromosomes and those not mapped or mapped to multi-positions in the Sscrofa10.2 assembly were discarded. A final set of 5,2596 SNPs on 18 autosomes with a unique position in Sscrofa10.2 was used for further analysis.

\section{CNV calling}

PennCNV was used to CNV calling. The software integrates a Hidden Markov Model (HMM) for high resolution copy number variation detection with whole-genome SNP genotyping data [4]. The signal intensity data of log R Ratio (LRR) and B allele frequency (BAF) were exported from Illumina BeadStudio software. Individual-based CNV calling was performed using the default parameters of the HMM model by integrating Log R Ratio, BAF, population allele frequency and the SNP distance.

To reduce the false discover rate in $\mathrm{CNV}$ calling, we used a calling criteria requiring that the standard deviation (SD) of LRR must be under or less 0.35 , the CNV contained three or more consecutive SNPs and the length of $\mathrm{CNV}$ region must be more than $50 \mathrm{~kb}$ at the calling-level. We set the "-qcnumcnv 50" argument in the command line to treat any samples with $>50 \mathrm{CNV}$ calls as low quality samples and eliminated them from analysis. GC model file was used to adjust the signal intensity values for $\mathrm{CNV}$ calling. For $\mathrm{F}_{2}$ individuals, the "-trio" argument was employed in CNV calling to make use of the family information. The CNVs whose $50.0 \%$ of sequence overlapped with the telomere region and those detected in only one individual and not overlapped with any other discovered $\mathrm{CNVs}$ were also removed from analysis. All putative CNVs identified in this study were pooled across breeds. We aggregated the overlapping CNVs identified across all samples to determine CNVRs following the previously published protocols [2].

\section{Quantitative real time PCR}

Seven CNVRs were randomly selected for validation by quantitative real time PCR (qPCR). The $2^{-\Delta \Delta \mathrm{Ct}}$ method was used to estimate relative quantification (RQ) of CNVRs [64]. This comparative method used a target assay for the $\mathrm{CNV}$ region and a reference assay of $\beta$-ACTIN as an internal control. The test and control primers were verified for their amplification efficiency. Six DNA samples were randomly selected including those with or without copy number variant for each CNVR. Primers and TaqMan probes labelled with FAM for each CNVR were designed with Allele 6.0 software (Applied Biosystems, Foster City, USA) and are listed in Additional file 2: Table S3. qPCR was carried out in a total volume of $20 \mu \mathrm{l}$ mixture containing $1 \times$ Premix Ex $\mathrm{Taq}^{\mathrm{TM}}$ (TaKaRa, Dalian, China), $0.2 \mu \mathrm{mol} / \mathrm{L}$ each primer, $1 \times$ ROX Reference Dye II and $100 \mathrm{ng}$ genomic DNA in 
an ABI 7500 FAST instrument (Applied Biosystems, Foster City, USA). The thermal cycle parameter was: $30 \mathrm{sec}$ at $95^{\circ} \mathrm{C}$, and $40 \mathrm{cycles}$ of $3 \mathrm{sec}$ at $95^{\circ} \mathrm{C}$ and $30 \mathrm{sec}$ at $60^{\circ} \mathrm{C}$. Each sample was analyzed in triplicate. Results were analyzed with the ABI7500 software v2.0.5 (Applied Biosystems, Foster City, USA).

\section{Gene identification and functional classification}

Genes within porcine CNVRs were annotated by BioMart [32]. These genes were tested for enrichment of molecule function, cell component and biological process in gene ontology (GO) terms in DAVID Bioinformatics Resources 6.7 [65]. Considering the limited number of pig genes assigned to GO terms, the human annotated genes that were homologous to pig genes were used as the background. Multiple tests were corrected by FDR corrections and enrichment threshold was set as EASE score of adjusted FDR $P \leq 0.05$.

\section{Statistical analysis}

Association of the CNV268 with $\mathrm{MCH}$ and MCV was analyzed with a mixed linear model. Gender and batch were considered as fixed effects. The QTL for $\mathrm{MCH}$ and $\mathrm{MCV}$ was re-mapped with the CNV268 as the fixed effect. All the analyses were performed with $\mathrm{R}$ package.

\section{Additional files}

Additional file 1: Table S1. CNVRs identified in this study and its state Additional file 2: Table S3. Primers and probes used for $\mathrm{QPCR}$ assays.

Additional file 3: Figure S1. The schematic diagrams depicting the validation of 7 CNVRs by quantitative real time PCR.

Additional file 4: Table S2. The distribution of CNVs and CNVRs in each of 18 diverse populations.

Additional file 5: Table S4. 1,055 well annotated genes located within the identified CNV regions. The 634 genes marked by * are also the copy number variable genes in human.

\section{Abbreviations \\ LD: Logissimus muscle; SOX5: Sex determining region Y-box 5: STX17: Syntaxin 17; FUT1: Alpha-1-fucosyltransferase; \\ APOE/C1/C4/C2: Apolipoprotein E/C1/C4/C2; KIT: V-kit Hardy-Zuckerman 4 feline sarcoma viral oncogene homolog; HADHA: Hydroxyacyl-CoA dehydrogenase, alpha subunit; HADHB: Hydroxyacyl-CoA dehydrogenase, belta subunit; KDR: Kinase insert domain protein receptor; ANP32B: Acidic (leucine-rich) nuclear phosphoprotein 32 family, member B; BSCL2: Berardinelli-Seip congenital lipodystrophy 2 (seipin); LTBP3: Latent transforming growth factor beta binding protein 3; GDF3: Growth differentiation factor 3; GYS1: Glycogen synthase 1; CAV1: Caveolin 1.}

\section{Competing interests}

The authors declare that they do not have any competing interests.

\section{Authors' contributions}

LSH, conceived and designed the experiments, revised the manuscript; CYC, performed the experiments, analyzed the data, wrote and revised the manuscript; RMQ, detected CNVs by PennCNV, performed the q-PCR assays and wrote part of draft. RXW: analyzed the data. JR, provided comments and suggestions for the manuscript; JWM: genotyped the $F_{2}$ individuals with $60 \mathrm{~K}$
SNP chip. HAS: mapped the SNPS to reference genome; YMG: analyzed the data. All authors read and approved the final manuscript.

\section{Acknowledgements}

We thank the colleagues in Key Laboratory for Animal Biotechnology of Jiangxi Province and the Ministry of Agriculture of China for their assistance in the management of resource population and sample collection. This work was supported by National Natural Science Foundation of China (31160225), National Key Basic Research Program of China (2012CB124702, 2012CB722502) and Program for Changjiang Scholars and Innovative Research Team in University (IRT1136).

\section{Author details}

${ }^{1}$ Key Laboratory for Animal Biotechnology of Jiangxi Province and the Ministry of Agriculture of China, Jiangxi Agricultural University, Nanchang 330045, China. ${ }^{2}$ Nanchang Working Canine Base, Nanchang 330045, China.

Received: 28 February 2012 Accepted: 15 December 2012

Published: 27 December 2012

\section{References}

1. Stankiewicz P, Lupski JR: Structural variation in the human genome and its role in disease. Annu Rev Med 2010, 61:437-455.

2. Redon R, Ishikawa S, Fitch KR, Feuk L, Perry GH, Andrews TD, Fiegler $H_{\text {, }}$ Shapero MH, Carson AR, Chen W, Cho EK, Dallaire S, Freeman JL, González JR, Gratacòs M, Huang J, Kalaitzopoulos D, Komura D, MacDonald JR, Marshall CR, Mei R, Montgomery L, Nishimura K, Okamura K, Shen F, Somerville MJ, Tchinda J, Valsesia A, Woodwark C, Yang F, Zhang J, Zerjal T, Zhang J, Armengol L, Conrad DF, Estivill X, Tyler-Smith C, Carter NP, Aburatani $\mathrm{H}$, Lee $\mathrm{C}$, Jones KW, Scherer SW, Hurles ME: Global variation in copy number in the human genome. Nature 2006, 444:444-454.

3. Marenne G, Rodríguez-Santiago B, Closas MG, Pérez-Jurado L, Rothman N, Rico D, Pita G, Pisano DG, Kogevinas M, Silverman DT, Valencia A, Real FX, Chanock SJ, Génin E, Malats N: Assessment of copy number variation using the Illumina Infinium 1 M SNP-array: a comparison of methodological approaches in the Spanish Bladder Cancer/EPICURO study. Hum Mutat 2011, 32:240-248.

4. Wang K, Li M, Hadley D, Liu R, Glessner J, Grant SF, Hakonarson H, Bucan M: PennCNV: an integrated hidden Markov model designed for highresolution copy number variation detection in whole-genome SNP genotyping data. Genome Res 2007, 17:1665-1674.

5. Colella S, Yau C, Taylor JM, Mirza G, Butler H, Clouston P, Bassett AS, Seller A, Holmes CC, Ragoussis J: QuantiSNP: an Objective Bayes Hidden-Markov Model to detect and accurately map copy number variation using SNP genotyping data. Nucleic Acids Res 2007, 35:2013-2025.

6. Gai X, Perin JC, Murphy K, O'Hara R, D'arcy M, Wenocur A, Xie HM, Rappaport EF, Shaikh TH, White PS: CNV Workshop: an integrated platform for high-throughput copy number variation discovery and clinical diagnostics. BMC Bioinformatics 2010, 11:74.

7. Winchester $L$, Yau C, Ragoussis J: Comparing CNV detection methods for SNP arrays. Brief Funct Genomic Proteomic 2009, 8:353-366.

8. Conrad DF, Pinto D, Redon R, Feuk L, Gokcumen O, Zhang Y, Aerts J, Andrews TD, Barnes C, Campbell P, et al: Origins and functional impact of copy number variation in the human genome. Nature 2010, 464:704-712.

9. Guryev V, Saar K, Adamovic T, Verheul M, van Heesch SA, Cook S, Pravenec M, Aitman T, Jacob H, Shull JD, Hubner N, Cuppen E: Distribution and functional impact of DNA copy number variation in the rat. Nat Genet 2008, 40:538-545.

10. Nicholas TJ, Cheng Z, Ventura M, Mealey K, Eichler EE, Akey JM: The genomic architecture of segmental duplications and associated copy number variants in dogs. Genome Res 2009, 19:491-499.

11. Hou Y, Liu GE, Bickhart DM, Cardone MF, Wang K, Kim ES, Matukumalli LK, Ventura M, Song J, VanRaden PM, Sonstegard TS, Van Tassell CP: Genomic characteristics of cattle copy number variations. BMC Genomics 2011, 12:127.

12. Doan $R$, Cohen N, Harrington J, Veazy K, Juras R, Cothran G, McCue ME, Skow L, Dindot SV: Identification of copy number variants in horses. Genome Res 2012, 22:899-907.

13. Stranger BE, Forrest MS, Dunning M, Ingle CE, Beazley C, Thorne N, Redon R, Bird CP, de Grassi A, Lee C, Tyler-Smith C, Carter N, Scherer SW, Tavaré S, Deloukas P, Hurles ME, Dermitzakis ET: Relative impact of nucleotide and 
copy number variation on gene expression phenotypes. Science 2007, 315:848-853.

14. Gamazon ER, Nicolae DL, Cox NJ: A study of CNVs as trait-associated polymorphisms and as expression quantitative trait loci. PLoS Genet 2011, 7:e1001292.

15. Tam GW, Redon R, Carter NP, Grant SG: The role of DNA copy number variation in schizophrenia. Biol Psychiatry 2009, 66:1005-1012.

16. Sha BY, Yang TL, Zhao LJ, Chen XD, Guo Y, Chen Y, Pan F, Zhang ZX Dong SS, Xu XH, Deng HW: genome-wide association study suggested copy number variation may be associated with body mass index in the Chinese population. J Hum Genet 2009, 54:199-202.

17. Schaschl H, Aitman TJ, Vyse TJ: Copy number variation in the human genome and its implication in autoimmunity. Clin Exp Immunol 2009, 156:12-16.

18. Cooper GM, Nickerson DA, Eichler EE: Mutational and selective effects on copy-number variants in the human genome. Nat Genet 2007, 39:S22-S29.

19. Wright D, Boije H, Meadows JR, Bed'hom B, Gourichon D, Vieaud A, Tixier-Boichard M, Rubin CJ, Imsland F, Hallböök F, Andersson L: Copy number variation in intron 1 of SOX 5 causes the Pea-comb phenotype in chickens. PLoS Genet 2009, 5:e1000512.

20. Rosengren Pielberg G, Golovko A, Sundstrom E, Curik I, Lennartsson J, Seltenhammer MH, Druml T, Binns M, Fitzsimmons C, Lindgren G, Sandberg K, Baumung R, Vetterlein M, Strömberg S, Grabherr M, Wade C Lindblad-Toh K, Pontén F, Heldin CH, Sölkner J, Andersson L: A cis-acting regulatory mutation causes premature hair graying and susceptibility to melanoma in the horse. Nat Genet 2008, 40:1004-1009.

21. Salmon Hillbertz NH, Isaksson M, Karlsson EK, Hellmén E, Pielberg GR, Savolainen P, Wade CM, von Euler H, Gustafson U, Hedhammar A, Nilsson M, Lindblad-Toh K, Andersson L, Andersson G: Duplication of FGF3, FGF4, FGF19 and ORAOV1 causes hair ridge and predisposition to dermoid sinus in Ridgeback dogs. Nat Genet 2007, 39:1318-1320.

22. Fontanesi L, Beretti F, Riggio V, Gómez González E, Dall'Olio S, Davoli R, Russo V, Portolano B: Copy number variation and missense mutations of the agouti signaling protein (ASIP) gene in goat breeds with different coat colors. Cytogenet Genome Res 2009, 126:333-347.

23. Johansson A, Pielberg G, Andersson L, Edfors-Lilja I: Polymorphism at the porcine Dominant white/KIT locus influence coat colour and peripheral blood cell measures. Anim Genet 2005, 36:288-296.

24. Pielberg G, Olsson C, Syvänen AC, Andersson L: Unexpectedly high allelic diversity at the KIT locus causing dominant white color in the domestic pig. Genetics 2002, 160:305-311.

25. Fadista J, Nygaard M, Holm LE, Thomsen B, Bendixen C: A snapshot of CNVs in the pig genome. PLoS One 2008, 3:e3916.

26. Tang H, Li F, Finlayson HA, Smith S, Lu Z, Langford C, Archibald AL: Structural and copy number variation in the pig genome. In Proceedings of the Plant \& Animal Genomes XVIII Conference: 9-13 January 2010; San Diego [abstract]. Edited by Gerard L, Vicoria Carollo B, David G.: 2010:609.

27. Ramayo-Caldas Y, Castello A, Pena RN, Alves E, Mercade A, Souza CA, Fernandez Al, Perez-Enciso M, Folch JM: Copy number variation in the porcine genome inferred from a 60 k SNP BeadChip. BMC Genomics 2010, 11:593.

28. Guo Y, Mao H, Ren J, Yan X, Duan Y, Yang G, Ren D, Zhang Z, Yang B, Ouyang J, Brenig B, Haley C, Huang L: A linkage map of the porcine genome from a large-scale White Duroc x Erhualian resource population and evaluation of factors affecting recombination rates. Anim Genet 2009, 40:47-52.

29. Ramos AM, Crooijmans RPMA, Affara NA, Amaral AJ, Archibald AL, Beever JE, Bendixen C, Churcher C, Clark R, Dehais P, Hansen MS, Hedegaard J, Hu ZL, Kerstens HH, Law AS, Megens HJ, Milan D, Nonneman DJ, Rohrer GA, Rothschild MF, Smith TPL, Schnabel RD, Van Tassell CP, Taylor JF, Wiedmann RT, Schook LB, Groenen MAM: Design of a high density SNP genotyping assay in the pig using SNPs identified and characterized by next generation sequencing technology. PLoS One 2009, 4:e6524.

30. Sebat J, Lakshmi B, Troge J, Alexander J, Young J, Lundin P, Månér S, Massa H, Walker M, Chi M, Navin N, Lucito R, Healy J, Hicks J, Ye K, Reiner A, Gilliam TC, Trask B, Patterson N, Zetterberg A, Wigler M: Large-scale copy number polymorphism in the human genome. Science 2004, 305:525-528.

31. Chen W, Hayward C, Wright AF, Hicks AA, Vitart V, Knott S, Wild SH, Pramstaller PP, Wilson JF, Rudan I, Porteous DJ: Copy number variation across European populations. PLOS One 2011, 6:e23087.

32. BioMart. www.biomart.org/.
33. Database of Genomic Variants. http://projects.tcag.ca/variation/.

34. Huang DW, Sherman BT, Lempicki RA: Systematic and integrative analysis of large gene lists using DAVID Bioinformatics Resources. Nature Protoc 2009, 4:44-57.

35. Young JM, Endicott RM, Parghi SS, Walker M, Kidd JM, Trask BJ: Extensive copy-number variation of the human olfactory receptor gene family. Am J Hum Genet 2008, 83:228-242.

36. Hussain A, Saraiva LR, Korsching SI: Positive Darwinian selection and the birth of an olfactory receptor clade in teleosts. PNAS 2009, 106:4313-4318.

37. Hediger MA, Romero MF, Peng JB, Rolfs A, Takanaga H, Bruford EA: The $A B C$ s of solute carriers: physiological, pathological and therapeutic implications of human membrane transport proteins: Introduction. Pflugers Arch 2004, 447:465-468

38. Chen R, Ren J, Li W, Huang X, Yan X, Yang B, Zhao Y, Guo Y, Mao H, Huang $L$ : A genome-wide scan for quantitative trait loci affecting serum glucose and lipids in a White Duroc x Erhualian intercross $F(2)$ population. Mamm Genome 2009, 20:386-392.

39. Ma J, Ren J, Guo Y, Duan Y, Ding N, Zhou L, Li L, Yan X, Yang K, Huang L, Song $Y$, Xie J, Milan D, Huang L: Genome-wide identification of quantitative trait loci for carcass composition and meat quality in a large-scale White Duroc $x$ Chinese Erhualian resource population. Anim Genet 2009, 40:637-647.

40. Ai H, Ren J, Zhang Z, Ma J, Guo Y, Yang B, Huang L: Detection of quantitative trait loci for growth- and fatness-related traits in a large-scale White Duroc $\times$ Erhualian intercross pig population. Anim Genet 2012, 43:383-391.

41. Ren DR, Ren J, Xing YY, Guo YM, Wu YB, Yang GC, Mao HR, Huang LS: A genome scan for quantitative trait loci affecting male reproductive traits in a White Duroc $x$ Chinese Erhualian resource population. $J$ Anim Sci 2009, 87:17-23.

42. Li K, Ren J, Xing Y, Zhang Z, Ma J, Guo Y, Huang L: Quantitative trait loci for litter size and prenatal loss in a White Duroc $x$ Chinese Erhualian resource population. Anim Genet 2009, 40:963-966.

43. Zou Z, Ren J, Yan X, Huang X, Yang S, Zhang Z, Yang B, Li W, Huang L: Quantitative trait loci for porcine baseline erythroid traits at three growth ages in a White Duroc $x$ Erhualian $F(2)$ resource population. Mamm Genome 2008, 19:640-646.

44. Mao H, Guo Y, Yang G, Yang B, Ren J, Liu S, Ai H, Ma J, Brenig B, Huang L: A genome-wide scan for quantitative trait loci affecting limb bone lengths and areal bone mineral density of the distal femur in a White Duroc x Erhualian F2 population. BMC Genet 2008, 9:63.

45. Pig QTL database. http://www.animalgenome.org/cgi-bin/QTLdb/SS/ index.

46. Reilly PT, Afzal S, Gorrini C, Lui K, Bukhman YV, Wakeham A, Haight J, Ling TW, Cheung CC, Elia AJ, Turner PV, Mak TW: Acidic nuclear phosphoprotein $32 \mathrm{kDa}$ (ANP32) B-deficient mouse reveals a hierarchy of ANP32 importance in mammalian development. Proc Natl Acad Sci USA 2011, 108:10243-10248.

47. Cui X, Wang Y, Tang Y, Liu Y, Zhao L, Deng J, Xu G, Peng X, Ju S, Liu G, Yang $\mathrm{H}$ : Seipin ablation in mice results in severe generalized lipodystrophy. Hum Mol Genet 2011, 20:3022-3030.

48. Dabovic B, Chen Y, Colarossi C, Obata H, Zambuto L, Perle MA, Rifkin DB: Bone abnormalities in latent TGF-[beta] binding protein (Ltbp)-3-null mice indicate a role for Ltbp-3 in modulating TGF-[beta] bioavailability. J Cell Biol 2002, 156:227-232.

49. Shen JJ, Huang L, Li L, Jorgez C, Matzuk MM, Brown CW: Deficiency of growth differentiation factor 3 protects against diet-induced obesity by selectively acting on white adipose. Mol Endocrinol 2009, 23:113-123.

50. Chen C, Ware SM, Sato A, Houston-Hawkins DE, Habas R, Matzuk MM, Shen MM, Brown CW: The Vg1-related protein Gdf3 acts in a Nodal signaling pathway in the pre-gastrulation mouse embryo. Development 2006, 133:319-329.

51. Bouskila M, Hunter RW, Ibrahim AF, Delattre L, Peggie M, van Diepen JA, Voshol PJ, Jensen J, Sakamoto K: Allosteric regulation of glycogen synthase controls glycogen synthesis in muscle. Cell Metab 2010, 12:456-466.

52. Magnol L, Chevallier MC, Nalesso V, Retif S, Fuchs H, Klempt M, Pereira P, Riottot M, Andrzejewski S, Doan BT, Panthier JJ, Puech A, Beloeil JC, de Angelis $\mathrm{MH}$, Hérault Y: KIT is required for hepatic function during mouse post-natal development. BMC Dev Biol 2007, 7:81. 
53. Waskow C, Paul S, Haller C, Gassmann M, Rodewald HR: Viable c-Kit(W/W) mutants reveal pivotal role for c-kit in the maintenance of lymphopoiesis. Immunity 2002, 17:277-288.

54. Tsujimura T, Koshimizu U, Katoh H, Isozaki K, Kanakura Y, Tono T, Adachi S, Kasugai T, Tei H, Nishimune Y: Mast cell number in the skin of heterozygotes reflects the molecular nature of c-kit mutation. Blood 1993, 81:2530-2538.

55. Rubin J, Schwartz Z, Boyan BD, Fan X, Case N, Sen B, Drab M, Smith D, Aleman M, Wong KL, Yao H, Jo H, Gross TS: Caveolin-1 knockout mice have increased bone size and stiffness. J Bone Miner Res 2007, 22:1408-1418.

56. Johansson Moller M, Chaudhary R, Hellmén E, Höyheim B, Chowdhary B, Andersson L: Pigs with the dominant white coat color phenotype carry a duplication of the KIT gene encoding the mast/stem cell growth factor receptor. Mamm Genome 1996, 7:822-830.

57. Xu GL, Ren J, Ding NS, Ai HS, Guo YM, Chen CY, Huang LS: Genetic analysis of the KIT and MC1R genes in Chinese indigenous pigs with belt-like coat color phenotypes. Anim Genet 2006, 37:518-519.

58. Lai F, Ren J, Ai H, Ding N, Ma J, Zeng D, Chen C, Guo Y, Huang L: Chinese white Rongchang pig does not have the dominant white allele of KIT but has the dominant black allele of MC1R. J Hered 2007, 98:84-87.

59. Meijerink E, Fries R, Vogeli P, Masabanda J, Wigger G, Stricker C, Neuenschwander S, Bertschinger HU, Stranzinger G: Two a $(1,2)$ fucosyltransferase genes on porcine chromosome $6 \mathrm{q} 11$ are closely linked to the blood group inhibitor (S) and Escherichia coli F18 receptor (ECF18R) loci. Mamm Genome 1997, 8:736-741.

60. Horák P, Urban T, Dvorák J: The FUT1 and ESR genes-their variability and associations with reproduction in Prestice Black-Pied sows. J Anim Breed Genet 2005, 122:210-213.

61. Ken-Dror G, Talmud PJ, Humphries SE, Drenos F: APOE/C1/C4/C2 gene cluster genotypes, haplotypes and lipid levels in prospective coronary heart disease risk among UK healthy men. Mol Med 2010, 16:389-399.

62. Kao HJ, Cheng CF, Chen YH, Hung SI, Huang CC, Millington D, Kikuchi T, Wu JY, Chen YT: ENU mutagenesis identifies mice with cardiac fibrosis and hepatic steatosis caused by a mutation in the mitochondrial trifunctional protein beta-subunit. Hum Mol Genet 2006, 15:3569-3577.

63. Li R, Yu C, Li Y, Lam TW, Yiu SM, Kristiansen K, Wang J: SOAP2: an improved ultrafast tool for short read alignment. Bioinformatics 2009, 25:1966-1967.

64. Livak KJ, Schmittgen TD: Analysis of relative gene expression data using real-time quantitative PCR and the 2(-Delta Delta $C(T)$ ) Method. Methods 2001, 25:402-408.

65. DAVID Bioinformatics Resources 6.7. http://david.abcc.ncifcrf.gov/.

doi:10.1186/1471-2164-13-733

Cite this article as: Chen et al: A comprehensive survey of copy number variation in 18 diverse pig populations and identification of candidate copy number variable genes associated with complex traits. BMC Genomics 2012 13:733.

\section{Submit your next manuscript to BioMed Central and take full advantage of:}

- Convenient online submission

- Thorough peer review

- No space constraints or color figure charges

- Immediate publication on acceptance

- Inclusion in PubMed, CAS, Scopus and Google Scholar

- Research which is freely available for redistribution 